\title{
Adaptation to Aquatic Risks due to Climate Change in Pangnirtung, Nunavut AUDREY R. GILES, ${ }^{1,2}$ SHAELYN M. STRACHAN,${ }^{3}$ MICHELLE DOUCETTE, ${ }^{4}$ GWENYTH S. STADIG, ${ }^{1}$ and THE MUNICIPALITY OF PANGNIRTUNG, NUNAVUT ${ }^{5}$
}

\author{
(Received 20 March 2012; accepted in revised form 25 July 2012)
}

\begin{abstract}
We use a vulnerability framework to examine how residents of Pangnirtung, Nunavut, perceive the risks of aquatic activities in the context of adaptation to a changing climate. Our findings suggest that community members identify climate change as increasing the risk of many aquatic activities and have adapted some practices accordingly. However, further adaptation to these changing risks is impeded by three main barriers: (1) financial constraints, (2) Inuit resistance to adopting what some consider Euro-Canadian water safety practices, and (3) issues with the design of flotation devices. Participants suggested the following practical changes: (1) make personal flotation devices, lifejackets, and floater suits available to all residents at local stores at a subsidized rate, or provide them free of charge through the community; (2) create water safety promotional items that feature locally developed messages in both Inuktitut and English; (3) include traditional knowledge in water safety campaigns; and (4) use the local pool to train residents in water safety. These changes would not only help residents adapt to changing risks, but also help incorporate climate considerations into policies and programs.
\end{abstract}

Key words: adaptation, climate change, water safety, Inuit, Pangnirtung, drowning, swimming pool, traditional knowledge, injury prevention

RÉSUMÉ. Nous utilisons un cadre de vulnérabilité pour examiner comment les habitants de Pangnirtung, au Nunavut, perçoivent les risques inhérents aux activités aquatiques dans le contexte de l'adaptation au changement climatique. Cette étude nous a permis de constater que les membres de la collectivité estiment que le changement climatique augmente le risque de nombreuses activités aquatiques et qu'ils ont modifié certaines de leurs manières de faire en conséquence. Cependant, trois grands obstacles entravent une adaptation plus poussée de ces risques : 1) les contraintes financières, 2) la résistance des Inuits à adopter ce que certains considèrent comme des méthodes eurocanadiennes plus sécuritaires, et 3) des problèmes de conception des appareils de flottaison. Les participants ont suggéré les changements pratiques suivants : 1) faire en sorte que des dispositifs de flottaison personnels, des gilets de sauvetage et des survêtements protecteurs soient à la disposition de tous les résidents à des prix subventionnés aux magasins de la région ou encore, qu'ils soient distribués aux gens gratuitement; 2) créer du matériel promotionnel élaboré localement, en anglais et en inuktitut, pour promouvoir la sécurité sur l'eau; 3) faire en sorte que des connaissances traditionnelles soient intégrées aux campagnes relatives à la sécurité sur l'eau; et 4) montrer aux habitants de la région des techniques de sécurité sur l'eau à la piscine locale. Ces initiatives aideront non seulement les résidents à s'adapter aux risques changeants, mais également à tenir compte des considérations climatiques dans le cadre de leurs programmes et politiques.

Mots clés : adaptation, changement climatique, sécurité sur l'eau, Inuit, Pangnirtung, noyade, piscine, connaissances traditionnelles, prévention des blessures

Traduit pour la revue Arctic par Nicole Giguère.

\section{INTRODUCTION}

Recent studies have noted that climate change is increasing the vulnerability of northern residents. Researchers have found that Northerners are experiencing changing ice and weather conditions (e.g., Laidler, 2006) and that there is a need for a stronger understanding of how Northerners can adapt to the risks that such changes pose to human health
(Ford et al., 2007). At the same time, high rates of injuries and fatalities related to boating, fishing, snowmobiling, swimming and other water activities in northern Canada have recently garnered scholarly attention (e.g., Giles et al., 2007, 2010a, b; Baker and Giles, 2008). However, these two related bodies of literature have not been combined. In this paper, we respond to calls to mainstream climate change adaptation policy, that is, to reduce vulnerability to climatic

\footnotetext{
${ }^{1}$ School of Human Kinetics, University of Ottawa, Ottawa, Ontario K1N 6N5, Canada

${ }^{2}$ Corresponding author: agiles@uottawa.ca

${ }^{3}$ Faculty of Kinesiology and Recreation Management, 102 Frank Kennedy Centre, University of Manitoba, Winnipeg, Manitoba R3T 2N2, Canada

${ }^{4}$ Institute of Population Health, 1 Stewart Street, University of Ottawa, Ottawa, Ontario K1N 6N5, Canada

${ }^{5}$ PO Box 253, Pangnirtung, Nunavut X0A 0R0, Canada

(C) The Arctic Institute of North America
} 
risks by integrating "the management of climate change risks into existing policy" (Ford et al., 2007:153) through the examination of vulnerability to climate change and to aquatic risks in Pangnirtung, Nunavut.

\section{Aquatic Injuries}

Despite a history of indigenous forms of water safety that dates from time immemorial (Giles et al., 2007; Baker and Giles, 2008) and extensive formalized Euro-Canadian water safety training that dates from 1967 (Giles et al., 2007), the Northwest Territories (NWT) and Nunavut (whose drowning data have typically been collapsed) report a drowning rate that varies between 5 and 10 times the Canadian national average (Waldram et al., 2006). In addition, Aboriginal residents of these territories drown more frequently than do non-Aboriginal residents (Giles et al., 2007). Past research has identified several reasons for the high drowning rate in northern Aboriginal populations: the failure to wear a lifejacket (also called a personal flotation device) or floater suit (Health Canada, 2001; Giles et al., 2010b); alcohol intoxication; low water temperatures; amount of time spent on or near water; limited access to swimming lessons and lifesaving training (Health Canada, 2001); and a lack of geographical and cultural relevance in current water safety programs and risk messaging (Giles et al., 2010a). Missing from this list, however, are considerations of climate change.

\section{Climate Change and Aquatic Risk}

The Arctic Climate Impact Assessment (ACIA, 2004) noted that climate change has brought unpredictable sea ice and weather conditions, changes in snow quality and characteristics, and less multi-year ice, all of which have increased risks to human health for Northerners who pursue activities such as snowmobiling, hunting, and fishing in or on Arctic waterways (Furgal et al., 2002; Nickels et al., 2005). While these changes have been documented through indigenous knowledge and Western scientific approaches (Kerr, 1999; Riedlinger and Berkes, 2001; Johannessen et al., 2004; Nichols et al., 2004; Nickels et al., 2005; Laidler, 2006), their possible contribution to injuries and deaths related to aquatic activities has received scant attention in water safety literature and programs. In addition, the few studies that have examined vulnerability in aquatic contexts (e.g., Ford et al.'s 2009 examination of sea ice) have not linked their results to existing water safety literature, programs, and promising practices.

\section{Aquatic Risk Perception and Communication}

Numerous studies have called for detailed research on individual and collective Aboriginal risk perspectives in Canada's North (Furgal et al., 1995, 2005; Kuhnlein and Chan, 2000; Poirier and Brooke, 2000; Duhaime et al., 2004; Myers and Furgal, 2006). In particular, Van Oostdam et al. (2005) identified the need to incorporate indigenous knowledge into understanding of risks related to Arctic issues and environments. The fact that injury and fatality statistics related to water are so high in the Northwest Territories and Nunavut suggests that strategies of communicating the risks of water activities in the Canadian North, especially among Aboriginal populations, have been ineffective. Therefore, perception and communication about these risks should be of special concern to Northerners and health researchers.

Giles et al. (2010a:2) argued that studies of Aboriginal Northerners' perceptions of aquatic risk and risk messages must account not only for the well-documented impacts of gender, age, ethnicity (Finucane et al., 2000; Satterfield et al., 2004), feelings (Slovic et al., 2004), and place (Masuda and Garvin, 2006), but also for the "specific historicopolitical relations embedded in places in which Aboriginal people have had ongoing relationships with non-Aboriginal settlers." In particular, Giles et al. (2010a) drew attention to the roles that trust and power play in water safety/risk messaging for Aboriginal Northerners. Giles et al. (2010a:8) argued that for aquatic risk communication strategies to be more successful amongst northern populations, "it is crucial that water safety programmers and risk communication experts recognize the ways in which the vestiges of colonialism continue to have an impact on place, program development, implementation, and uptake," e.g., by including Inuit knowledge in water safety programs and risk communication efforts.

\section{CONCEPTUAL FRAMEWORK}

Giles et al.'s (2010a) findings on aquatic risk coalesce with those of Ford et al. (2007) concerning vulnerability to climate change. Ford et al. (2007:153) argued, "Interventions to reduce vulnerability will be more successful if they are identified and developed in co-operation with local actors, as the community will be more likely to trust them and find them consistent with local goals and norms." In short, Ford et al. (2007) and Giles et al. (2010a) have argued for full Inuit involvement in the design and implement of interventions that are intended for their use.

Ford et al. (2006) and Smit and Wandel (2006) developed a vulnerability approach to analyze the impact of climate change on Inuit populations. They suggested that by using place-based case studies that characterize current human vulnerability to climate change, researchers can more confidently assess future vulnerability and identify adaptation strategies. Many other authors have since used this approach (e.g., Andrachuk, 2008; Laidler et al., 2009; Pearce et al., 2010). Ford et al. (2007:153) outlined five steps in their approach to assessing current vulnerability:

1) identify conditions that represent risks to community members, 2) characterize how communities experience and manage climatic risks, 3) identify the processes and 
conditions that influence exposure to climatic hazards and determine the efficacy, availability, and success of past and present adaptations, 4) identify opportunities for and constraints on adapting to climate change, and 5) identify entry points for adaptation policy.

Ford et al. (2007:153) argued that once such information is established, one can assess future vulnerability to climate-related risks and whether or not community members "will be capable of dealing with these risks." That knowledge will allow mainstream adaptation policy to include the management of climate change risks. Such an approach can be situated within what Smit and Wandel (2006) have identified as practical adaptation initiatives - research that focuses on a region's or community's adaptive capacity or needs so that adaptation initiatives can be implemented or adaptive capacity can be enhanced. The focus of such research "is to document the ways in which the system or community experiences changing conditions and the processes of decision-making in this system (or that influence the system) that may accommodate adaptations or provide means of improving adaptive capacity" (Smit and Wandel, 2006:285). These findings can then be mainstreamed into climate change policy (Ford et al., 2007). We would also argue, however, that in addition to mainstreaming such understanding into climate-related policy, practical adaptation initiatives need to include considerations of climaterelated risks in health promotion programs, such as those that focus on drowning prevention.

Endeavoring to use a vulnerability approach to inform practical adaptation initiatives, the first three authors travelled to Pangnirtung, Nunavut, to work in partnership with the Hamlet of Pangnirtung and local residents. The goal was to understand how Pangnirtungmiut have adapted to climate-related aquatic risk and the ways in which these findings could be used to strengthen existing water safety programs and policies.

\section{METHODS}

The Municipality of Pangnirtung, Nunavut, located on southwest Baffin Island $\left(66^{\circ} 05^{\prime} \mathrm{N}, 65^{\circ} 45^{\prime} \mathrm{W}\right)$, has a population of 1325, of which 1240 identify themselves as Inuit (Statistics Canada, 2007). Pangnirtung was selected as the research site for several reasons. The community was initially selected because in the summer of 2008 the Hamlet had planned to open a new local swimming pool and the first author was conducting research concerning the pool's impact on residents' views of water safety. Because the pool did not in fact open that summer, the research shifted in focus from the pool to an investigation of water, boat, and ice safety practices in natural aquatic environments (e.g., the Arctic Ocean, rivers, and fiords). During the summer of 2008, we conducted semi-structured interviews with seven male and nine female residents who ranged in age from 5 to 84 . These interviews sensitized us to how community members viewed the role of climate change in water-related injuries. The authors then partnered with the municipality to obtain funding for research on how climate change affects the risk of aquatic activities.

In November of 2008, the first two authors traveled to Pangnirtung for an intensive week of data collection with 24 additional residents. We held three focus groups: one with three men and four women ranging in age from their early 20 s to mid $40 \mathrm{~s}$; one with one male and four female high school students; and one with two boys and two girls ranging in age from 11 to 14 . In addition, we held eight semi-structured interviews with individuals ranging in age from 26 to 90 . Thus, in total, we interviewed 40 participants, 17 women and 23 men. We conducted all focus groups in English, while we used the services of a local interpreter for several interviews with Elders.

In February 2009, the first and third authors returned to the community to verify the initial findings with the interviewees and focus group participants. During all visits, the authors conducted participant observation (Dewalt and Dewalt, 2002) by joining in community activities and taking careful notes on aquatic practices that they witnessed in day-to-day community life. All participants gave informed consent, and those who gave permission to be named are identified in the text.

\section{RESULTS}

We transcribed interview and focus group data verbatim in English. We then manually coded these data and our field notes. Following Creswell (2009), we organized the data and then examined them for three kinds of codes: 1) those related to the relevant bodies of literature, 2) those that were unexpected, and 3) those that related directly to the theoretical framework. We then grouped the codes in categories based on the vulnerability framework: the identification of conditions that represent risks (codes: weather change and ice change), risk management (codes: lifejackets, floater suits, and preparation), constraints on adaptation (codes: financial constraints, non-Inuit behaviour, and design), and opportunities for adaptation (Inuit knowledge, swimming, and equipment lists).

\section{Identification of Conditions that Represent Risks}

All adult interviewees reported that they had witnessed the impact of climate change. Jay Kilabuk, a young adult male, said he had noticed several different signs of climate change:

Ya...the weather is different. [In the past in] October the [natural ice] arena would open, but now it opens in like December to January, that's like a couple months later now. And the [sea] ice can't really freeze now. Usually, like when I was a little kid, we would go Halloween trick-or-treating when [there] was lots of snow, we 
would go on a skidoo, but now, today, there's no snow at all...And about the weather, like, it's more rough...it gets rough all of a sudden now.

One female Elder stated, "I notice now, too, that the ice melts a lot faster. Back then [in the past] even in July we used to be able to travel by dog team. The ice goes just like that now...It takes a lot longer to form and isn't as thick as it used to be." Jay Kilabuk further noted the danger associated with changing ice conditions and snowmobiling:

There are weak spots more now on the ice, like you can even tell, there are black, dark black colour or something like that, that goes down. You can see it with the ice...I can't tell them, but Elders can.

However, it is important to note that Elder Elisapee Ishulutaq stated that she too had difficulty in detecting the presence of unsafe water and ice conditions: the "water is more dangerous...even when...there's ice it's hard to tell if it's really thin ice or not."

Community members were especially concerned about the effect of climate change on hunters' safety. A male resident in his 20 s echoed other community members' concerns about their use of snowmobiles on thin ice: "It makes it harder for hunters to go out hunting due to climate change because the ice breaks so much sooner. One Elder stated, 'It's a lot more dangerous [now], especially for hunters... right now it is very dangerous, as they can go through thin ice."'

According to an anonymous male, changes in ice thickness are especially dangerous for inexperienced hunters:

For new generation hunters, it's going to be more dangerous for sure, because they're just losing their Inuit traditional knowledge, like they're getting their traditions from down South, like new traditions, like new technology.

\section{Risk Management}

Given that Pangnirtung residents generally viewed the ice as thinner and weaker (and thus less stable) and the weather and water conditions as less predictable, we asked residents about how they managed their exposure to risk. Flotation devices were generally viewed as being important in the management of aquatic risks. For example, one Elder said, "It's safer to wear lifejackets." Further, most participants stated that they believed that flotation devices should be present in boats to better manage risk. In reference to floater suits and lifejackets, a male in his 20s stated, "many people got [lifejackets] in their boat...just in case if something happens...like if the weather is bad or the weather is windy or something, [then] you really have to keep that jacket and use it."

Other ways of managing risk involved ensuring that one was adequately prepared for going out on the land.
Residents expressed concerns that young community members were not taking such precautions. For instance, Simeonie Akpalialuk, an experienced hunter, stated:

The evidence shows that in the last 10 years here in Nunavut, there has been many young fatalities out on the land because they don't have the skills or the knowledge to be out there. The number one problem is they're not prepared. Every time we go out on the land, even if it's for half-hour or one day, we bring all our survival gear, our sleeping gear, our tents, food, and extra parts, but the young people they just take off in just the skidoo, no provisions, nothing. They figure if they go one hour by ski-doo, they aren't that far. Well... it's dangerous.

\section{Adapting to Climate Change-Related Aquatic Risks}

Participants identified several constraints on their ability or their willingness to adapt (or both) to increasingly risky aquatic situations: financial constraints, the perception that wearing floater suits and lifejackets represents Euro-Canadian or non-Inuit behaviour, and issues with the design of flotation devices. Participants also identified opportunities for adapting to climate change-related aquatic risks through the use of Inuit knowledge and the local swimming pool.

Financial Constraints: Many interviewees suggested that residents cannot afford flotation devices. Meeka Alivaktuk stated:

Only people who can afford to buy them [wear them]. So there are a lot of kids who don't use them, like for boating... Some people can't afford to buy them because they're very expensive. So some take a lot of risk.

One young male adult noted, "with the cost of freight and prices, it's so expensive...most people can't afford lifejackets for the whole family...I think that it is definitely worth it, but the money's really tight up here." Indeed, several interviewees reported that children were more likely to wear lifejackets in a boat than adults. Meeka Alivaktuk reported, "Kids are first - they come first." Nevertheless, one young interviewee, who stated that she wears a lifejacket when boating but that her parents do not, noted, "It makes me feel like I'm the only one who's a bit safer."

Despite reports of flotation device usage, results from participant observation suggested that community members rarely wore them. This finding is perhaps best illustrated by the remarks made by young adult Bonnie Etanguat, who noted that once she "saw one family - they were using lifejackets" (her emphasis). Participants stated that rather than wearing flotation devices, community members more often had them available in their boats. In the words of one young male adult, "they're just there." Nevertheless, Ooleepeeka Arnaqaq believed that "more and more people are starting to use the floater suits." In terms of the adult population, 
throughout the summer the researchers saw only non-Inuit adults who were tourists wearing floater suits or lifejackets while boating.

Over the course of the summer, the researchers occasionally witnessed children who were playing in the cold, shallow water from the Duval River, which runs through the hamlet, wearing one of several lifejackets that were left at the site. Given the depth of the water, however, it appeared that the children wore the lifejackets to keep warm and to find amusement in their flotation properties rather than for reasons of injury prevention.

Non-Inuit Behaviour: Despite the general opinion that flotation devices are important for water safety and adapting to climate change, a few participants didn't wear them because they felt that doing so would reflect non-Inuit behaviour. When asked about lifejackets, one young woman stated, "White people want that [lifejackets]...'Cause they [are] all white, and in the North we're Inuit. We just go... Most White people will wear a lifejacket." This same young woman reported that she thought that the practice of wearing lifejackets was a "little bit weird." One middle-aged Inuit man said forcefully, "The White man and the Eskimo are different. Think about it. Our grandfathers didn't wear lifejackets in the kayaks - the White man and the Eskimo are different!"

Design Issues: When we probed further about what keeps residents from wearing flotation devices, several reported that they felt that these devices are designed in such a way that they impede users' ability to hunt, fish, and, perhaps most interestingly, to be safe. Simeonie Akpalialuk reported:

I know in talking with other hunters, we don't wear [floater suits]. It becomes, for us, very restrictive in our ability to move, and our ability to quickly do things, where... traditionally the way I grew up, my agility, my balance, and [ability to] quickly be able to react in different instances, I can probably survive better if I start falling or something like that-I can quickly react and correct myself. But with a floater suit on, I'm so restricted... I'm in more danger... [when]...I have it on. I won't be able to react to correct myself quickly enough or go to someone quickly enough because this floater suit is restricting my movements. And for that reason, myself, I won't wear it. The only time I would probably wear it is to keep myself warm...The people that actually make [the floater suit] don't think about these things. It's bulky, it's heavy, and especially if it's wet...So, in some cases, it's not practical.

Two young women who were interviewed separately made similar statements, saying that when wearing a floater suit, they do not "have enough reach," which referred to the fact that they believe a floater suit inhibits their mobility while in a boat, something that was deemed to be especially problematic in terms of being able to assist with hunting and fishing activities. In fact, several participants commented that the lack of flexibility in floater suits makes it difficult to shoot a rifle when wearing one. A male Elder further noted that floater suits are not suitable for Arctic climates:

The suit needs to be updated...because during winter time when we are wearing the suit, it's not very effective to keep the person warm. And, during the summer and springtime...when they're wearing a flotation suit the person tends to sweat a lot because it's kind of too warm to wear that suit...It might be too cold, it might be too warm. So it's those things that we need to look into also.

Participants identified what they felt were two other floater suit design flaws: fit and aesthetics. Selina Kisa stated that she felt that floater suits are not designed for Inuit people, in that the legs and arms are too long for those who are generally short in stature. In a similar vein and to much agreement, one member of the adult focus group stated that floater suits need to be redesigned to be "shorter and with room for a belly." Finally, one young male participant stated succinctly, "I think that a lot of people choose not to wear lifejackets because they kind of look goofy."

Though Pangnirtungmiut identified several constraints to their adaptation to climate change, they also identified several things that would assist with their adaptation: the use of Inuit knowledge, the use of the local swimming pool, and ensuring that community members had access to lists of culturally and geographically relevant equipment that they should bring with them when participating in aquatic activities.

Inuit Knowledge: Some interviewees reported that Inuit knowledge and oral traditions have been, are, or should be used more frequently to keep Inuit safe in aquatic environments. Simeonie Akpalialuk argued that adaptation to climate change needs to be informed by Elders who hold Inuit knowledge: "I would start with my Elders. I would get a group of them, get their knowledge on let's say, for example, if we want to design a floater-suit that is acceptable here. Well, let's go to the Elders, we can think about the design, how to sew, what materials to put in, and things like that." Traditional clothing was noted as having potentially lifesaving qualities. For example, Elisapee Ishulutaq remembered that when she was a child, her "younger sister fell in the water when she was clothed in caribou clothing - she floated from her clothing! The water doesn't soak through as quickly as [manufactured] material does. She didn't even look scared when my dad grabbed her. She had a big smile on her face!"

The vast majority of interviewees cited the use of an oral tradition about sea monsters (Qallupilluit) as a way of keeping children safe around the water. According to a middleaged woman, children "would always be told that there are sea monsters in the water and that if they got into the water that the sea monsters would put them in the amautik [Inuit parka] and bring them down [to the bottom of the ocean] with them." Similarly, one young girl stated, "My grandparents have told me about legends of creatures that 
are called Qallupilluit that steal children if you are around the water alone. And that you never come back unless you figure out a way to escape them." Elder Elisapee Ishulutaq also noted that Elders used to tell her these stories when she was a child, which would "terrify" her. She noted that children "used to respect their Elders whenever an Elder told them something. They're not like that now. It's almost like the kids are changing with the weather. Like the world [is] changing, the kids are changing too." Elder Adamee Komortok similarly noted:

A lot of the old traditions have pretty much died off, ... sort of discontinued. We know the story behind some of them, but...these people who would normally practice it are old enough [to] not really be out hunting anymore, so we are at a point where... a younger generation is more or less doing the hunting now and... they were never brought up with [that] sort of a tale, so they're not really into it.

Komortok further noted that he was not exposed to many "water traditions":

In my early days, I got taken out [of the community] and [spent] five years in residential schools, so I missed a lot of things people at my age during that five year period would have witnessed and would have been taught...I just didn't have any contact with my people for a long period at that time.

Swimming as Adaptation: Participants identified water safety instruction, particularly swimming lessons at the yet-to-be opened pool, as having the ability to teach and encourage people to be safe around water. Elder Elisapee Ishulutaq noted that she felt that teaching water, boat, and ice safety would be very effective in a swimming pool setting, that it would "have a better effect on the children" than teaching such information on the land. Meeka Alivaktuk stated, "if I was drowning or if I got in the water by accident, I should have some techniques to climb on the water, like stay on the water. That's why I want to learn to stay on the water. How do they stay on the water? They make it look so easy." Elder Adamee Komortok similarly argued:

Young people we can teach from every age how to... stay afloat and swim if necessary... Once they have that lesson, they will utilize it if they get into situations where they fall into the water-they will swim...I can guarantee you that. And if they're fairly close to shore or some object where they can...get off the water, that's exactly what they're going to do. You know, having that kind of a program [at the pool] when they're...pretty young is the way to go, and down the road it will help them. And drowning situations in the older days are no longer drowning situations if someone knows how to swim, so that's what it's going to take: young people being in swimming lessons earlier on.
Elders were seen as having the potential to play important roles within swimming lessons. One man related a sentiment often expressed by the research participants: "It would be great to have Elders involved at the pool." Meeka Alivaktuk agreed and noted, "[Elders] have techniques, not swimming, but in a different way...to stay on the safe side of thin ice."

Equipment: Pangnirtung residents stated that aquatic risks could be reduced by ensuring that community members have access to lists of aquatic equipment that is culturally and geographically relevant in the context of a changing climate. From the focus group and semi-structured interview transcripts, we identified those items that residents deemed necessary for safe boating: warm clothing, sleeping gear, tent, CB radio, satellite phone, global positioning system, maps, food, tea pot, jerry cans, stove and fuel, rifle and ammunition, hunting gear, hooked harpoon, knives, shovel, a first aid kit, floater suits and lifejackets, and rope. Participants suggested that a list of these items should be made available in both Inuktitut and English and that they would be particularly effective if printed on promotional items such as thermoses, which residents were likely to take out on the land.

\section{DISCUSSION}

Our results show that Pangnirtung residents view aquatic activities as increasingly risky because of climate change. Despite their perception of greater vulnerability and the historically high drowning rates, the majority of interviewees did not report adapting to increased vulnerability by wearing lifejackets, PFDs, or floater suits, which represent the most prevalent approach in current water safety programs. They did, however, cite using Inuit knowledge, using the local swimming pool, and creating equipment lists as strategies they use or would like to use to reduce vulnerability. Below, we discuss ways in which flotation devices could be used in adaptation strategies and how flotation devices, Inuit knowledge, the local swimming pool, and equipment lists could be entry points for mainstreaming existing policies and programs to help reduce Pangnirtungmiut's vulnerability to climate-related aquatic risks.

\section{Flotation Devices}

Our data revealed three main barriers to Pangnirtung residents' adoption of flotation devices: (1) financial constraints, (2) resistance to adopting what some consider to be Euro-Canadian practices, and (3) design issues. In discussing these findings, we suggest ways to overcome these barriers and enable a more robust range of offerings for adaptation.

Inuit in Nunavut face high levels of poverty. According to Canada's 2006 Census (Statistics Canada, 2007), the average earnings for a person in Pangnirtung were \$20 069 . While this figure is above the Canadian low-income cut-off 
for communities of fewer than 30000 people, that comparison does not take into account the cost of living in Nunavut, which is substantially higher than in the rest of Canada. For example, according to Aboriginal Affairs and Northern Development Canada (2010), the total cost of a weekly food basket for a family of four costs $\$ 189$ in Ottawa, but $\$ 396$ in Pangnirtung. Not surprisingly, interviewees reported that the high cost of floater suits, lifejackets, and PFDs served as a major deterrent to purchasing these safety items, a result that corroborates the findings of Giles et al. (2010b) from research with Inuit residents of Taloyoak, Nunavut, and Inuvialuit residents of Tuktoyaktuk, Northwest Territories.

Pangnirtung residents also reported that because of the high cost, they were more likely to purchase flotation devices for children than for adults. Having children and not adults wear flotation devices is a problematic way of adapting to aquatic risk for several reasons. First, drowning statistics for northern Canada show that adults, and particularly adult males, are more vulnerable to drowning than children, so it is important for them to wear flotation devices (CRC, 2007). Second, to maximize the chance that children will wear lifejackets, it is important for adults to model that behaviour. Treser et al. (1997) found that children are more likely to wear lifejackets in a boat when adults onboard are wearing them, but adults are not more likely to put on lifejackets when children are wearing them. Third, in the event of an accident, it is important for children to receive help from adults. If adults are not wearing flotation devices and struggle to stay afloat, they might be hindered in their attempts to help their children reach safety.

As adaptation through the use of flotation devices is inhibited by financial constraints, it is important to offer these devices to all community members at a reduced cost or free of charge. Offering flotation devices free of charge and having them more widely available might increase usage and decrease drowning. A 1997 study in Alaska noted that lifejacket wear increased from $16 \%$ to $35 \%$ following the installation of a "loaner" lifejacket station (Office of Boating Safety, 2011). Alaska's "Kids don't Float" program makes lifejackets freely available to Alaska residents. Boards that read "Kids don't float: Give them something that does" have hooks attached to them from which lifejackets hang. These "loaner boards" are found in outdoor locations where children tend to swim. The program has been credited with saving at least 15 lives (Office of Boating Safety, 2011). More recently, an observational study of lifejacket wear conducted by the Alaska Boating Safety Program, District 17 of the U.S Coast Guard, and the Alaska Department of Health and Social Services showed that in the areas with loaner programs, the wear rates for children up to 17 years of age increased by $25 \%$ (Office of Boating Safety, 2011). While these data reflect children's wear rates, flotation device use by adults might also be increased by providing the same services. However, it is important to note that the cost and availability of flotation devices are not the only constraints that need to be addressed, as our data show that even when flotation devices are available, they are rarely worn.

To better understand why local residents seem reluctant to wear flotation devices, we examine the context in which the aquatic safety behaviours occur. Inuit in Canada have experienced an incredibly rapid change to their ways of life, including safety practices, over the past 70 years. Saylor (2004:313), who examined the use of safety equipment in Aboriginal communities, noted that:

Unlike in the non-Aboriginal world, [cars, snowmobiles, etc.] arrived much more abruptly in [Aboriginal] communities. Safety measures such as seat belts, car seats, helmets and other injury prevention interventions were not included at the time. Even today...personal flotation devices are not commonly used.

Certainly, colonial interventions into Inuit life have included the imposition of foreign laws and policies, including those pertaining to safety. Several participants noted that flotation devices were unwelcome Euro-Canadian interventions into their Inuit lifestyle. Water, ice, and boat safety campaigns developed in southern Canada use images (e.g., trees, warm weather, and southern Canadians) that differ vastly from the view encountered daily by Inuit in Pangnirtung. Such images do not help to connect southernderived safety practices and risk messages with Inuit lifestyles and practices (Giles et al., 2010a).

The perception that water safety is a Euro-Canadian practice is also problematic as it ignores the rich history of Inuit knowledge pertaining to water safety (cf. Giles and Baker, 2007; Giles et al., 2007, 2010a; Baker and Giles, 2008). Including local Inuit knowledge in water safety programs and campaigns might improve residents' willingness and ability to adapt to aquatic risk and thus increase their options for reducing their vulnerability.

Pangnirtung residents share their reasons for not wearing flotation devices with other Canadians. Groff and Ghadiali (2003) reported that three of the five main reasons why Canadians do not wear flotation devices are that they consider them unattractive or unfashionable, find them uncomfortable, and think they restrict movement. Participants in our study similarly reported that they believe flotation devices are "kind of dorky," poorly designed for the purposes for which they would use them - that is, hunting and fishing - and that they did not believe that such devices have the capacity to keep them safe. Indeed, a few participants expressed the belief that wearing a flotation device heightened their risk of accidental drowning.

Fishing immersion deaths (drowning while engaged in fishing activities) make the largest contribution to drowning fatalities in Canada (CRC, 2009). The rate of fishing immersion deaths is highest in the Canadian North (the Yukon, NWT, and Nunavut). Canada-wide statistics show that not one of the people who drowned while engaged in subsistence fishing from a boat, $91 \%$ of whom were Aboriginal, was wearing a flotation device (CRC, 2009). These 
data suggest that it is unlikely that wearing flotation devices increases aquatic risk: if that were the case, presumably more people would be found drowned and wearing a flotation device. Nevertheless, the assertion that the design of flotation devices needs improvement if more Pangnirtung residents are to wear them and feel safe and comfortable while doing so must be taken seriously.

The Alaska Eskimo Whaling Commission, the United States Coast Guard, the Alaska Native Tribal Health Consortium, and Mustang Survival (a flotation device manufacturer) recently joined forces to create a custom float coat-a full jacket made with buoyant materials that also provide thermal protection - for Native Alaskan whalers. The whalers expressed a desire for flotation devices that were white, a colour that they believe does not scare the animals they hunt. Mustang Survival thus produced a white float coat to meet these needs. The white float coat has proven to be immensely popular within the target population (Barber, 2010). These results lend further credence to the assertion that projects and programs that meaningfully include Northerners' input will have better success in meeting the challenge of Northerners' adaption to climate change (Ford et al., 2007).

Because of attention generated by the drowning death of a community member while boating in the summer of 2011, the Hamlet of Pangnirtung is currently in discussions with several organizations to help to determine which kind and brand of flotation device would best meet community members' needs. The Hamlet hopes to use revenue generated by the sales of plastic bags at the local Northern Store to offset the cost of purchasing flotation devices for each boat in the community. However, flotation devices (such as floater suits) for those engaged in snowmobiling also require attention, yet do not appear to be the community's main area of current concern.

\section{Opportunities for Adaptation}

Though community members do not currently use flotation devices to adapt to what they perceived as increased aquatic risks due to climate change, they suggested other strategies for enhancing adaptation efforts. Participants identified the use of Inuit knowledge, swimming pools, and equipment lists as promising interventions that could be mainstreamed into climate change adaptation efforts.

Inuit knowledge, the term that we will use to refer to the knowledge held by Inuit that pertains to their environment (Laidler, 2006) and cultural practices, is currently marginalized within aquatic injury prevention programs, which are typically produced by organizations like the Canadian Red Cross Society and the Lifesaving Society of Canada that are based in southern Canada. Nevertheless, community members noted that this traditional knowledge is important for keeping Inuit safe in aquatic environments.

These findings corroborate and extend previous research findings. For instance, in their study of aquatic risk communication and water safety practices in Taloyoak, Nunavut, and Tuktoyaktuk, Northwest Territories, Giles et al. (2010a) found that when communicated by respected Elders, traditional knowledge could play a key role in reducing aquatic risk. One community member from Tuktoyaktuk went so far as to say, "We listen to our Elders. You live longer that way" (Giles et al., 2010a:5). Nevertheless, also in line with our findings, several other authors have noted that some forms of northern traditional knowledge, though important for safety (Aporta and Higgs, 2005), are no longer as effective as in the past because of changing climate conditions (McDonald et al., 1997; George et al., 2004; Laidler et al., 2009) or a lack of familiarity with Inuit knowledge pertaining to aquatic risk (Giles et al., 2010a), or both. Those who design policies and programs to promote adaptation to climate change and prevent aquatic injury need to realize that while it is of key importance to include Northerners' expert knowledge (Furgal et al., 2002) and technologies (such as traditional clothing and harpoons), we must also bear in mind that this knowledge, like all forms of knowledge, changes over time.

One of the more unusual ways that participants identified for adapting further to climate-related aquatic risk was to use the local swimming pool. While recreation coordinators and swimming pool supervisors have not typically been viewed as helping Inuit communities adapt to climate change, they could play a key role by creating meaningful programs through which local residents can learn or share ways to adapt in order to remain safe in risky aquatic environments.

Interviewees identified the need to include Elders in designing and implementing swimming pool programming, as they believed that Elders would have a great deal of practical information to share about how to stay safe in natural aquatic environments. Swimming pools in the North are typically staffed by seasonal southern Canadian workers, such as university and college students, because finding certified Northerners to run these facilities has proved to be challenging (Giles et al., 2007). Since such workers are often unfamiliar with Arctic environments, they are not well equipped to help community members cope with situations that rarely occur in southern Canada. Community members thought it would be beneficial for Elders to participate in leading swimming pool programs. However, Giles et al. (2010a) found in Taloyoak, Nunavut, and Tuktoyaktuk, Northwest Territories, that several barriers exist. These include Elders' lack of formal lifeguarding qualifications, contemporary Elders' lack of traditional knowledge about water-related safety practices, and youths' lack of respect for Elders. Innovative programs that pair knowledgeable, respected Elders with certified lifeguards to offer water safety programming in tandem could provide solutions to these issues and help residents adapt further to climate change. As the Hamlet of Pangnirtung's pool has yet to open because of issues related to the building in which it is housed, it is still possible to design the pool's programs around the needs of community members rather than using pre-packaged programs from the south. 
Participants advocated developing lists of items on products like thermoses that they believed would remind Pangnirtung residents of what they need to bring with them during aquatic activities to prepare for unpredictable water and ice conditions. Existing lists, such as Transport Canada's (2010) minimum safety equipment requirements for boating, are in English and French only, and they fail to include equipment that is uniquely suited to Pangnirtung residents' needs. For example, Transport Canada's (2010) list does not include a rifle, ammunition, harpoon, or knives, all of which were deemed crucial by Pangnirtung residents. We cross-referenced the list of items that Pangnirtung residents identified as necessary with Transport Canada's list of items required to be on all boats and created a list that meets both groups' requirements. Because the budget was limited and they wished to create products that would be useful to community members, the research team designed thermos bottles and magnets with the equipment list printed on them in Inuktitut and English. Future research could evaluate the uptake of locally derived adaptation techniques and whether such items have the effects predicted by community members.

Future research should also focus on whether adaptation through the use of aquatic safety equipment such as floater suits results in risk compensation: the phenomenon of individuals' engaging in "greater risk taking behavior when wearing safety gear compared to when not doing so" (Morrongiello et al., 2007:56). For instance, the use of floater suits by Pangnirtungmiut could have the paradoxical effect of decreasing their engagement with other forms of injury prevention and climate-change adaptation efforts. Further, the reliance on new technologies, like GPS, could result in disengagement from Inuit knowledge about the environment and navigation (Aporta and Higgs, 2005). These considerations demonstrate the need for further understanding of the complex relationships between climate change adaptation and injury prevention, particularly in an aquatic context.

\section{ACKNOWLEDGEMENTS}

The authors are grateful to the Social Sciences and Humanities Research Council of Canada and Health Canada for funding that made this research possible, the editors and reviewers for their very helpful feedback, and the participants for welcoming us into Pangnirtung.

\section{REFERENCES}

Aboriginal Affairs and Northern Development Canada. 2010. Regional results of price surveys. http://www.ainc-inac.gc.ca/ eng/1100100035986.

ACIA (Arctic Climate Impact Assessment). 2004. Impacts of a warming Arctic. Cambridge: Cambridge University Press. $140 \mathrm{p}$.
Andrachuk, M. 2008. An assessment of the vulnerability of Tuktoyaktuk to environmental and socio-economic changes. MA thesis, University of Guelph, Guelph, Ontario.

Aporta, C., and Higgs, E. 2005. Satellite culture: Global positioning systems, Inuit wayfinding, and the need for a new account of technology. Current Anthropology 46(5):729-753.

Baker, A.C., and Giles, A.R. 2008. Pedagogy of the front float: Dialogue and aquatics programming in Taloyoak, Nunavut. Arctic 61(3):233-242.

Barber, V. 2010. Whaler "float coat" to order. The Arctic Sounder, May 5. http://www.anthc.org/chs/wp/injprev/upload/ArcticSounder-Whaler-float-coat-to-order-5-10.pdf.

CRC (Canadian Red Cross). 2007. Lifejackets and personal flotation devices (PFDs). http://www.redcross.ca/article. asp?id $=015198 \&$ tid $=024$.

- 2009. Drownings and other water-related injuries in Canada: 10 years of research. Module 5: Fishing. Ottawa: Canadian Red Cross.

Creswell, J.W. 2009. Research design: Qualitative, quantitative, and mixed methods approaches, 3rd ed. Thousand Oaks, California: Sage.

Dewalt, K.M., and Dewalt, B.R. 2002. Participant observation: A guide for fieldworkers. Walnut Creek, California: AltaMira Press.

Duhaime, G., Chabot, M., Fréchette, P., Robichaud, V., and Proulx, S. 2004. The impact of dietary changes among the Inuit of Nunavik (Canada): A socioeconomic assessment of possible public health recommendations dealing with food contamination. Risk Analysis 24(4):1007-1018, doi:10.1111/ j.0272-4332.2004.00503.x.

Finucane, M.L., Alhakami, A., Slovic, P., and Johnson, S.M. 2000. The affect heuristic in judgments of risks and benefits. Journal of Behavioral Decision Making 13(1):1 - 17.

Ford, J.D., Smit, B., Wandel, J., and MacDonald, J. 2006. Vulnerability to climate change in Igloolik, Nunavut: What we can learn from the past and present. Polar Record 42(221):127-138, doi:10.1017/S0032247406005122.

Ford, J., Pearce, T., Smit, B., Wandel, J., Allurut, M., Shappa, K., Ittusujurat, H., and Qrunnut, K. 2007. Reducing vulnerability to climate change in the Arctic: The case of Nunavut, Canada. Arctic 60(2):150-166.

Ford, J.D., Gough, W.A., Laidler, G.J., MacDonald, J., Irngaut, C., and Qrunnut, K. 2009. Sea ice, climate change, and community vulnerability in northern Foxe Basin, Canada. Climate Research 38(2):137-154, doi:10.3354/cr00777.

Furgal, C., Shortreed, J., Keith, R., Craig, L., and Dewailly, E. 1995. Inuit perspectives on environmental contaminants: Report on Avativut/Ilusivut risk management workshops in Nunavik and Labrador: 16-17 January 1995, Kuujjuaq, Québec and 18-19 January 1995, Nain Labrador. Waterloo, Ontario: Institute for Risk Research, University of Waterloo.

Furgal, C.M., Martin, D., and Gosselin, P. 2002. Climate change and health in Nunavik and Labrador: Lessons from Inuit knowledge. In: Krupnik, I., and Jolly, D., eds. The Earth is faster now: Indigenous observations of Arctic environmental change. Fairbanks: Arctic Research Consortium of the 
United States in cooperation with the Arctic Studies Center, Smithsonian Institution. 266-299.

Furgal, C.M., Powell, S., and Myers, H. 2005. Digesting the message about contaminants and country foods in the Canadian North: A review and recommendations for future research and action. Arctic 58(2):103-114.

George J.C., Huntington, H.P., Brewster, K., Eicken, H., Norton, D.W., and Glenn, R. 2004. Observations on shorefast ice dynamics in Arctic Alaska and the responses of the Iñupiat hunting community. Arctic 57(4):363-374.

Giles, A.R., and Baker, A.C. 2007. Culture, colonialism, and competition: Youth sport culture in Canada's North. In: Giardina, M.D., and Donnelly, M.K., eds. Youth cultures and sport: Identity, power, and politics. London: Routledge. $161-174$.

Giles, A.R., Baker, A.C., and Rousell, D.D. 2007. Diving beneath the surface: The NWT Aquatics Program and implications for Aboriginal health. Pimatisiwin: A Journal of Aboriginal and Indigenous Community Health 5(1):25-49.

Giles, A.R., Castleden, H., and Baker, A.C. 2010a. "We listen to our Elders. You live longer that way": Examining aquatic risk communication and water safety practices in Canada's North. Health and Place 16(1):1-9.

Giles, A.R., Strachan, S.M., Stadig, G., and Baker, A.C. 2010 b. "Don't be scared, you don't have to wear your lifejacket": Using the theory of planned behaviour to understand lifejacket usage in Tuktoyaktuk, Northwest Territories, Canada. Polar Record 46(4):328 - 335, doi:10.1017/S0032247409990180.

Groff, P., and Ghadiali, J. 2003. Will it float? Mandatory PFD wear legislation: A background research paper. Prepared for the Canadian Safe Boating Council. Toronto, Ontario: SMARTRISK.

Health Canada. 2001. Unintentional and intentional injury profile for Aboriginal People in Canada, 1990-1999. Ottawa: First Nations and Inuit Health Branch, Community Health Programs Directorate.

Johannessen, O.M., Bengtsson, L., Miles, M.W., Kuzmina, S.I., Semenov, V.A., Alekseev, G.V., Nagurnyi, A.P., et al. 2004. Arctic climate change: Observed and modelled temperature and sea-ice variability. Tellus 56A(4):328-341, doi:10.1111/ j.1600-0870.2004.00060.x.

Kerr, R.A. 1999. Will the Arctic Ocean lose all its ice? Science 286(5446):1828, doi:10.1126/science.286.5446.1828.

Kuhnlein, H., and Chan, H. 2000. Environment and contaminants in traditional food systems of northern indigenous peoples. Annual Review of Nutrition 20:595-626, doi:10.1146/annurev. nutr.20.1.595.

Laidler, G.J. 2006. Inuit and scientific perspectives on the relationship between sea ice and climate change: The ideal complement? Climatic Change 78(2-4):407-444, doi:10.1007/ s10584-006-9064-z.

Laidler, G.J., Ford, J.D., Gough, W.A., Ikummaq, T., Gagnon, A.S., Kowal, S., Qrunnut, K., and Irngaut, C. 2009. Travelling and hunting in a changing Arctic: Assessing Inuit vulnerability to sea ice change in Igloolik, Nunavut. Climatic Change 94(34):363 - 397, doi:10.1007/s10584-008-9512-z.
Masuda, J.R., and Garvin, T. 2006. Place, culture, and the social amplification of risk. Risk Analysis 26(2):437-454, doi:10.1111/j.1539-6924.2006.00749.x.

McDonald, M., Arragutainaq, L., and Novalinga, Z., eds. 1997. Voices from the Bay: Traditional ecological knowledge of Inuit and Cree in the Hudson Bay bioregion. Ottawa: Canadian Arctic Resources Committee; Sanikiluaq, Nunavut: The Municipality of Sanikiluaq.

Morrongiello, B.A, Lasenby, J., and Walpole, B. 2007. Risk compensation in children: Why do children show it in reaction to wearing safety gear? Journal of Applied Developmental Psychology 28(1):56-63, doi:10.1016/j.appdev.2006.10.005.

Myers, H., and Furgal, C. 2006. Long-range transport of information: Are Arctic residents getting the message about contaminants? Arctic 59(1):47-60.

Nichols, T., Berkes, F., Jolly, D., Snow, N.B., and the Community of Sachs Harbour. 2004. Climate change and sea ice: Local observations from the Canadian Western Arctic. Arctic 57(1):68-79.

Nickels, S., Furgal, C., Buell, M., and Moquin, H. 2005. Unikkaaqatigiit - Putting the human face on climate change: Perspectives from Inuit in Canada. Ottawa: Inuit Tapiriit Kanatami, Nasivvik Centre for Inuit Health and Changing Environments at Université Laval, and the Ajunnginiq Centre at the National Aboriginal Health Organization.

Office of Boating Safety. 2011. Kids don't float Program. http:// dnr.alaska.gov/parks/boating/kdfhome.htm.

Pearce, T., Smit, B., Duerden, F., Ford, J.D., Goose, A., and Kataoyak, F. 2010. Inuit vulnerability and adaptive capacity to climate change in Ulukhaktok, Northwest Territories, Canada. Polar Record 46(237):157-177, doi:10.1017/S00322474090086 02.

Poirier, S., and Brooke, L. 2000. Inuit perceptions of contaminants and environmental knowledge in Salluit, Nunavik. Arctic Anthropology 37(2):78-91.

Riedlinger, D., and Berkes, F. 2001. Contributions of traditional knowledge to understanding climate change in the Canadian Arctic. Polar Record 37(203):315 - 328, doi:10.1017/S003224740 0017058.

Satterfield, T.A., Mertz, C.K., and Slovic, P. 2004. Discrimination, vulnerability, and justice in the face of risk. Risk Analysis 24(1):115-129, doi:10.1111/j.0272-4332.2004.00416.x.

Saylor, K. 2004. Injuries in Aboriginal children. Paediatrics and Child Health 9(5):312-314.

Slovic, P., Finucane, M.L., Peters, E., and MacGregor, D.G. 2004. Risk as analysis and risk as feelings: Some thoughts about affect, reason, risk, and rationality. Risk Analysis 24(2):311 - 322, doi:10.1111/j.0272-4332.2004.00433.x.

Smit, B., and Wandel, J. 2006. Adaptation, adaptive capacity, and vulnerability. Global Environmental Change 16(3):282-292, doi:10.1016/j.gloenvcha.2006.03.008.

Statistics Canada. 2007. Pangnirtung, Nunavut (Code6204009) (table). Aboriginal population profile, 2006 census. Ottawa: Statistics Canada Catalogue no. 92-594-XWE. Released January 15, 2008. http://www12.statcan.ca/censusrecensement/2006/dp-pd/prof/92-594/index.cfm?Lang=E. 
Transport Canada. 2010. Minimum safety equipment required for the size and type of your pleasure craft. http:/www.tc.gc.ca/ eng/marinesafety/debs-obs-equipment-size-menu-690.htm.

Treser, C.D., Trusty, M.N., and Yang, P.D. 1997. Personal flotation device usage: Do educational efforts have an impact? Journal of Public Health Policy 18(3):346-356, doi:10.2307/3343315.
Van Oostdam, J., Donaldson, S.G., Feeley, M., Arnold, D., Ayotte, P., Bondy, G., Chan, L., et al. 2005. Human health implications of environmental contaminants in Arctic Canada: A review. Science of the Total Environment 351-352:165-256, doi:10.1016/j.scitotenv.2005.03.034.

Waldram, J.B., Herring, D.A., and Young, K.T. 2006. Aboriginal health in Canada: Historical, cultural, and epidemiological perspectives, 2nd ed. Toronto: University of Toronto Press. 